\title{
The Comparison between National Final Examination Test Items and English Teacher Made-Test Items of 2010 and 2011
}

\author{
Khairil Razali*1 \\ English Department, Faculty of Education and Teacher Training UIN Ar-Raniry \\ ${ }^{1}$ E-mail: balimemory2004@googlemail.com \\ Miftahul Jannah \\ English Department, Faculty of Education and Teacher Training UIN Ar-Raniry \\ E-mail: Miftahul jannah@yahoo.com \\ DOI: http://dx.doi.org/10.15548/jt.v22i1.116
}

\begin{abstract}
The objective of the paper is to determine the relevance between the scope of the national final examination test items in English lesson and the English teacher made test items. It is also to identify the relevance between the deepness of national final examination test items in English subject and the English teacher made test item. The finding showed that more than fifty percents of tryout out test items are not relevant with the national test items. Meanwhile, the final national test items were design with higher cognitive domain than teacher made test items. It means the teacher made test items (tryout) is more superficial than final national test items. It can be a reason why the students who are can pass the tryout test which is made in teacher cannot pass the national final examination test (standardized test). It is expected that this study provides empirical evidence to devise on their optimal uses in EFL teaching.
\end{abstract}

Keywords: National Final Examination Test Items, English teacher-made test Items

\section{INTRODUCTION}

In teaching and learning process, evaluation is usually conducted by the teacher in order to assess the student's understanding about the materials. According to Arikunto (2005), evaluation is used to know the results of teaching-learning process. In addition, she said that "the standard of education result can be figured out by evaluation" (Arikunto, 2005:3). In line with Arikunto's opinion about the meaning of evaluation, Ralph Tyler in Tayibnapis (2000) stated that "evaluation is a process that determines to what extend the educational target can be reach"(Farida, 2000). To gain a valid result of teaching-learning process, the teacher should need a tool. One of tools that can be used to evaluate the students' achievement is a test.
Based on test constructor, there are two kinds of test, standardized and teacher madetests. According to Anderson (as cited in Arikunto), the word standard means "a degree of level of requirement, excellence, or attainment"(Arikunto, 2005:145). Encyclopedia Brintanica stated that "Standardized tests with carefully defined procedures for administration and scoring to ensure uniformity can achieve broader goals" (http://www.britannica.com). In this sense, the standardized test is a test that is made by some certain institutions or some departments of education. For example, national final examinations test. In short, the standardized test is a test made by some certain institution and it is participated by the same degree of level students.

Another kind of test is teacher-made test. According to Arikunto (2000), the teacher made test is "test that is arranged by the teacher 
in the same type of question and consist of the same amount of materials or knowledge which are included by teacher made test" (Arikunto, 2005: 146). Further, teacher made test is "tests and other measures that are planned, assembled, written, or otherwise prepared by teachers for use with particular groups of students" (http://www.education.com).

General principles of test construction and such considerations as reliability and validity apply to both types of test (http://www.britannica.com). However, even both types of tests apply the general principles of test construction and such considerations as reliability and validity, actually, there are many students who pass the teacher-made test cannot pass the final examinations which are standardized test. This is become a problem in our educational system right now. Hence, the writer wants to know whether the pertinent teachers use Standar Kompetensi Lulusan (SKL) or not in conducting the test as guidance.

Encouraged by the above facts, the writer is interested in conducting the research on this problem, what will be the relevance between the scopes of the national final examination test items in English lesson. In this article, the researcher explored the following two questions:

1. What would be the relevance between the scope of the national final examination test items in English lesson and the English teacher made test items?

2. What would be the relevance between the deepness of national final examination test items in English subject and the English teacher made test items?

\section{METHOD}

Research methodology is defined how the data acquired in order to answer the research question. (Subagyo, 1991:16). In this sense, the writer examined document analysis because it is one of descriptive qualitative research method. Qualitative descriptive research provides an answer to the questions of how something happened and who was involved, but not why something happened or why someone was involved (explanatory research) (Carol Strider, http://www.eHow.pdf)

In this research, the writer stumbled on the data or the documents that needed in order to answer the writer's research questions. In addition, the writer achieved the document analysis, observation and interview in order to gather more information that the writer needed in answering the research questions.

Document analysis was accomplished by the writer in order to gather information used in national final examination test items document and information used in teacher made test items. Also, document analysis was also used to study the content of the document.

The writer would find out the document of national final examination test items and the document of the Luqman Al Hakim Senior High School English teacher made test items (in this sense, the test such a try-out test that made in teacher in that school), then the writer analyzed it until she get the answer of her research question. Interview defined as a meeting of people face to face especially for consultation. (http://www.interview.htm). According to Subagyo, interview is "an activity conducted in order to get information directly by laying open questions at the responder". (P. Joko Subagyo, 1991: 39).

In this research, interview addressed to the teacher who made the test in order to get more information about the teacher made test. The researcher arranges some questions that ask about the test which made by the English teacher.

Data analysis started with analyzing entire available data from the national final examination test items document and the try out test items document. Then, continued with data reduction; the process of selecting, focusing, simplifying, abstracting, and transforming the data that appear in transcriptions (Miles and Huberman, 1994: 10). After that, the field notes 
is arranged steadily in order to make it easy to re ensure anytime the writer need it.

To obtain the data in this research, the writer used the analysis descriptive method, a method that focus on explaining and solving the problem in a period of time which is real by collecting the data and analyzing the data objectively (Margono, 2005: 125).

\section{RESEARCH FINDINGS}

Data of interviews and document analysis are going to be discussed here as follow:

Table 1. The Relevance of Tryout test items and national final test items

\begin{tabular}{|c|c|c|}
\hline $\begin{array}{l}\text { Number } \\
\text { of Tryout } \\
\text { Test Items }\end{array}$ & Theme & Explanation \\
\hline $1-4$ & Recount text & $\begin{array}{l}\text { Those questions are not } \\
\text { relevant to national } \\
\text { final examination test } \\
\text { items because there is } \\
\text { no question about } \\
\text { narrative text in } \\
\text { national final } \\
\text { examination test items. } \\
\text { However, it was } \\
\text { relevant to the pass } \\
\text { competence standard } \\
\text { given by the } \\
\text { government. }\end{array}$ \\
\hline $5-9$ & Explanation text & $\begin{array}{l}\text { Those questions are not } \\
\text { relevant to national } \\
\text { final examination test } \\
\text { items because there is } \\
\text { no question about } \\
\text { narrative text in } \\
\text { national final } \\
\text { examination test items. } \\
\text { However, it was } \\
\text { relevant to the pass } \\
\text { competence standard } \\
\text { that has given by the } \\
\text { government. }\end{array}$ \\
\hline $\begin{array}{c}10-15 \\
\& \\
38-39\end{array}$ & Narrative text & $\begin{array}{l}\text { Those questions are not } \\
\text { relevant to national } \\
\text { final examination test } \\
\text { items because there is } \\
\text { no question about }\end{array}$ \\
\hline
\end{tabular}

\begin{tabular}{|c|c|c|}
\hline & & $\begin{array}{l}\text { narrative text in } \\
\text { national final } \\
\text { examination test items. } \\
\text { However, it was } \\
\text { relevant with the pass } \\
\text { competence standard } \\
\text { that has given by the } \\
\text { government. }\end{array}$ \\
\hline $\begin{array}{c}16-19 \\
\& \\
40-43\end{array}$ & $\begin{array}{l}\text { Hortatory } \\
\text { exposition }\end{array}$ & $\begin{array}{l}\text { Those questions are } \\
\text { relevant to final } \\
\text { examination test } \\
\text { because it was design } \\
\text { based on the lattice } \\
\text { work that has given by } \\
\text { the government. It was } \\
\text { question the same } \\
\text { aspect with final } \\
\text { examination test, such } \\
\text { as asking about the text } \\
\text { purposes. It was also } \\
\text { design based on } \\
\text { common materials and } \\
\text { targets of school. }\end{array}$ \\
\hline $\begin{array}{c}20-23 \\
\& \\
44-47\end{array}$ & Descriptive text & $\begin{array}{l}\text { Those questions are not } \\
\text { relevant to national } \\
\text { final examination test } \\
\text { items because there is } \\
\text { no question about } \\
\text { narrative text in } \\
\text { national final } \\
\text { examination test items. } \\
\text { However, it was } \\
\text { relevant to the pass } \\
\text { competence standard } \\
\text { that has given by the } \\
\text { government. }\end{array}$ \\
\hline $24-25$ & Procedure text & $\begin{array}{l}\text { Those questions are } \\
\text { relevant to final } \\
\text { examination test } \\
\text { because it was design } \\
\text { based on the lattice } \\
\text { work that has given by } \\
\text { the government. It was } \\
\text { also design based on } \\
\text { common materials and } \\
\text { targets of school. }\end{array}$ \\
\hline $\begin{array}{c}26-27 \\
\& \\
33-37\end{array}$ & $\begin{array}{l}\text { Analytical } \\
\text { exposition }\end{array}$ & $\begin{array}{l}\text { Those questions are } \\
\text { relevant to final } \\
\text { examination test } \\
\text { because it was design } \\
\text { based on the lattice } \\
\text { work that has given by } \\
\text { the government. It was } \\
\text { question the same } \\
\text { aspect with final } \\
\text { examination test. It was } \\
\text { also design based on }\end{array}$ \\
\hline
\end{tabular}




\begin{tabular}{|c|c|c|}
\hline & & $\begin{array}{l}\text { common materials and } \\
\text { targets of school. }\end{array}$ \\
\hline $\begin{array}{c}28-30 \\
\& \\
48-50\end{array}$ & Report text & $\begin{array}{l}\text { Those questions are } \\
\text { relevant to final } \\
\text { examination test } \\
\text { because it was design } \\
\text { based on the lattice } \\
\text { work that has given by } \\
\text { the government. It was } \\
\text { question the same } \\
\text { aspect with final } \\
\text { examination test, such } \\
\text { as asking about main } \\
\text { idea. It was also design } \\
\text { based on common } \\
\text { materials and targets of } \\
\text { school. }\end{array}$ \\
\hline $31-32$ & $\begin{array}{l}\text { Advertisement } \\
\text { text }\end{array}$ & $\begin{array}{l}\text { Those questions are not } \\
\text { relevant to national } \\
\text { final examination test } \\
\text { items because there is } \\
\text { no question about } \\
\text { narrative text in } \\
\text { national final } \\
\text { examination test items. } \\
\text { However, it was } \\
\text { relevant to the pass } \\
\text { competence standard } \\
\text { that has given by the } \\
\text { government. }\end{array}$ \\
\hline
\end{tabular}

Based on the table above, even the tryout test items has been design based on SKL, however, it can be seen that there is almost $54 \%$ of tryout test items are not relevant to the national final examination test items. It just $46 \%$ of it that is relevant to the national final examination test items.

In brief, more than fifty percents of tryout out test items is not relevant to the national test items. This is why the students who can passed the tryout test which is made by the English teacher cannot pass the national final examination test as a standardized test.

\section{DISCUSSION}

Evaluation is defined variously, depending on the subject matter, applied methodology or the application of its results. In general, the definition of evaluation can be stated as judgement on the value of a public intervention with reference to defined criteria of this judgement. (http://www.fundusze strukturalne.gov.pl)

Evaluation is a research about development and students' progress related to the reinforcement of the material given and values which is in curriculum (Sudjono, 2005:1). Maddelena (2005) in her paper stated that the terms evaluation or assessment are both in common usage in educational circles. In United Kingdom (UK), the common use of the term 'assessment' is to refer to judgments of students' work and 'evaluation' to refer to judgments concerning courses or course delivery or the process of making of such judgments.

There are many definitions of evaluation; the following are some of them.

According to Subiyanto (1988), evaluation is process that was taken up by someone in order to get useful information to determine which of alternatives wish are for (Subiyanto, 1988: 6). Sadler (as cited in Hopkins) stated that "evaluation is a dominating aspect of educational practice. It strongly influences what students attend to, how hard they work, how they allocate their study time, and what they can afford to get interested in" (Hopkins, 1990: 11). Further, evaluation is performed in order to distinguish someone's achievement in their study (Subiyanto, 1988: 8).

In broad outline, it can be said that evaluation is the process of awarding value toward quality of something. Otherwise, evaluation is also understandable as a process of planning, reaching, and preparing information that are really needed in order to create the alternative decision. Thereby, evaluation is a systematically process that is conducted in order to establish or to make decision to what extend the aim of the teaching learning have been reached by the students. (Purwanto, www. Navel's Blog.htm). 
Based on the various definitions above, it can be said, evaluation is a process of assessing and measuring the students' achievement by using some tools in teaching learning process.

\section{Formal and Informal Evaluation}

Formal evaluations are exercises or procedures specifically designed to tap into a storehouse of skills and knowledge. They are systematic, planned sampling techniques constructed to give teacher and student an appraisal of student achievement (Brown, 2004:6). In this case, we can say that all tests are formal evaluation, but not all formal evaluation is testing.

On the other hand, informal evaluation can take a number of forms, starting with incidental, unplanned comments and responses, along with coaching and other impromptu feedback to the student (Brown, 2004:5)

\section{Formative Evaluation and Summative Evaluation}

Two general instructional purposes for assessment are discussed in the literature. Assessment data are either collected for summative or formative evaluations, both of which are important to the instructional process and lead to improved outcomes (Burn, 2008).

Formative evaluation is evaluating students in the process of forming their competencies and skills with the goal of helping them to continue that growth process. For all practical purposes, virtually all kinds of informal evaluation are should be formative. Formative evaluation is often conceptualized as the collection of data to monitor student progress (Brown, 2004:6).

Summative evaluation aims to measure or summarize what a student has grasped, and typically occurs at the end of a course or unit of instruction. Final exams in a course and general proficiency exams are examples of summative evaluation (Brown, 2004:6).
In conclusion, the formative test is usually given in each part of learning while the summative test is given at the end of classes.

\section{Bloom's Learning Objective Classification}

Since categories of learning objectives reflect the way conceptualize such nations as knowledge and learning, the range of learning objectives is as wide as range of conception of knowledge and learning. According to Bloom et.al when educational psychologist write about objectives they have tended to use term like "cognitive", "affective", and "psychomotor". While in the past or more recently, Gagne stated that they have tended to use term like "motor skill", "verbal information", "cognitive strategies", "intellectual skills", and "attitude"(Posner, 2004:78).

Three domain of objectives that Bloom, et. al classified are:

\section{Cognitive domain}

Cognitive domain is the domains that include all the mental activity. Bloom stated that effort that related to the brain activity is in relationship to the cognitive phase. In this phase there are six scaffolds of thinking, from the low level of scaffold till the high one. Those six scaffolds are knowledge, comprehension, application, analysis, synthesis and evaluation.

\section{Affective domain}

Affective domain is the domain that related to the attitude and value; include emotional aspects, such as receiving, responding, valuing, organization and characterization.

\section{Psychomotor domain}

Psychomotor domain is the domain related to the creativity or the ability to act after someone receiving some certain learning experiences. This domain is consists of five criteria, those are: set, imitation, habitual, adaptation, and creation. This taxonomy is the criteria that can be used by teachers to evaluate 
the quality and learning effectively (Nasution. 1998:65)

In this research, researcher only study about cognitive domain because it is almost always use by teacher in evaluating their students. Because of that, researcher will only discuss about the cognitive domain that have stated by Bloom of the three domains above.

Bloom et.al described six major of cognitive objectives, those are:

1. Knowledge or recall and memorize $(\mathrm{C} 1)$

Knowledge here means that the level of ability which only ask the respond toward the students to know about the fact, concepts or terminology without must be understood, can be valuing and can be used it. In this term, students are demanded to recall or only to memorize it.

The formulated indicator which usually measure the level of reinforcement, is usually used the operational words such as, mention, direct, know, remember, and define. (Ngalim Purwanto, 2004: 43).

\section{Comprehension $(\mathrm{C} 2)$}

Comprehension here means that the ability level which apply toward student to be able to comprehend the meaning and concept, and the situation and the fact that the student knows. It is also about understanding the literal message contained in a communication.

Knowledge of comprehension can be distinguish to be three phases, those are:

a. Knowledge of translation comprehension

b. Knowledge of interpretation comprehension, and

c. Knowledge of extrapolation comprehension

The operational words that usually used to formulate the indicator of study by this scaffold are, differ, change, prepare, set, describe, demonstrate, giving example, guess, determine, and decision making.

\section{Application $(\mathrm{C} 3)$}

In this domain, someone's ability to apply and to use the common ideas, methods, principles, formulas, theories, etc, are use the concept of problem solving. For example, a student is able to think about the concept of application that has been taught in daily activity, whether in school, environment and society. (Anas Sudjono, 2005:1). It is also knowing how and when to use an abstract in a new situation and problem.

The operational words that is usually use are, use, apply, connect, choose, develop, organize, arrange, and change the structure. The application knowledge is easier to measure by the test in form of essay rather than objective test.

\section{Analysis (C4)}

Analysis means as someone ability in using the knowledge to solve a lot of problems in daily activity. For example, students can analyze how far they know about the discussion they done. (Hamzah B. Uno, 2006: 36).

Analysis also described as breaking down "material into its constituent parts and detecting" relationship of part and of the way they recognize.

The operational used are differ, find out, classify, categorize, analysis, and compare, etc.

5. Synthesis (C5)

Student's ability in uniting several elements of the knowledge until formed new pattern. For example, students can set their own learning activity plan consistent with the rule of their school. (Hamzah B. Uno, 2006: 37).

To formulate this indicator, the operational words used are count, specify, classify, organize, develop, conclude, etc.

6. Evaluation (C6)

Evaluation is making judgments about the value for some purposes of ideas, works, solutions, methods, and materials, etc. By the 
evaluation ability, student is demanded to design an assessment about a statement, concept, and situation, based on certain criteria. This activity can be seen from its aim side, the way of its solving, its method, and its material.

The form of the internal criteria of the evaluation can be a probability measurement, a situation, apply a certain criteria in an product, know the consistency, perfection, relevancy of data, differ the validation of an argument, etc. External criteria of evaluation formed are comparing a product to another, compare a theories with a culture facts, etc. (Ngalim Purwanto, 2004: 47).

The operational words that usually use in formulating the indicator of study are interpret, determine, consider, compare, do, decide, and argue.

Then, all indicators can be more classify into evaluation instrument, where it is consist of kind of evaluation, instrument evaluation form and example of instrument. All in all, that is all the explanation about the level of cognitive competence that it is use to be very important for teacher in designing the learning result test based on the indicator of study.

In taxonomy domain includes the operational verbs which are describe the form of action that will be achieved through the learning process. To make it clearly, the below table will show the example of cognitive operational verbs), as can be seen in the following table:

Table 1

The Example of Cognitive Operational Verbs

\begin{tabular}{|c|c|c|c|c|c|}
\hline $\begin{array}{l}\text { Know- } \\
\text { ledge }\end{array}$ & $\begin{array}{l}\text { Compr } \\
\text { hensio }\end{array}$ & $\begin{array}{l}\text { Appli- } \\
\text { cation }\end{array}$ & Analysis & $\begin{array}{l}\text { Syn- } \\
\text { thesis }\end{array}$ & $\begin{array}{l}\text { Evalua- } \\
\text { tion }\end{array}$ \\
\hline To quote & $\begin{array}{l}\text { To } \\
\text { explain }\end{array}$ & To apply & $\begin{array}{l}\text { o analyze } \\
\text { o find }\end{array}$ & $\begin{array}{l}\text { To } \\
\text { abstract }\end{array}$ & To compare \\
\hline $\begin{array}{l}\text { To } \\
\text { mention }\end{array}$ & $\begin{array}{l}\text { To } \\
\text { fontrast }\end{array}$ & $\begin{array}{l}\text { To } \\
\text { evaluate }\end{array}$ & heasure & $\begin{array}{l}\text { To } \\
\text { collect }\end{array}$ & \begin{tabular}{|l} 
To \\
conclude \\
To predict
\end{tabular} \\
\hline To state & $\begin{array}{l}\text { To } \\
\text { differ }\end{array}$ & To solve & o Study & To & \\
\hline To sign & To & To & o diagnose & $\begin{array}{l}\text { categori } \\
\text { ze }\end{array}$ & To decide \\
\hline To write & $\begin{array}{l}\text { Change } \\
\text { To }\end{array}$ & $\begin{array}{l}\text { Construct } \\
\text { To }\end{array}$ & & To & To consider \\
\hline
\end{tabular}

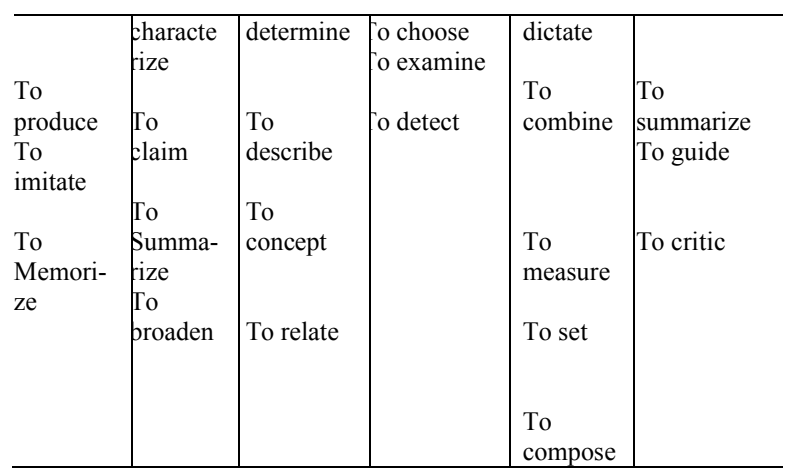

Based on Bloom description above, it is visible that the learning objectives must be involving all individual action domains. Its means, not only focus on cognitive and intellectual changes only, that's what, is still found in Indonesia's educational practice.

The activity of formulating the learning objectives basically is teacher's authority, thus for in line with the applying of democratic and participative learning, then in designing the learning objectives, beside consistent with the curriculum, teacher should be involving the students in it. The involving of students in designing the learning objectives make students to be easily motivated and focus on every teaching learning process. In this problem, every teacher is demanded to have a creativity to meet the learning objectives as written in curriculum with the demand of fulfillment and the students' learning objectives.

\section{Definition of Test}

In order to expand a valid result of teaching-learning process, the teacher should need a tool. Test is one of tools that can be used to evaluate the students' achievement.

Test is procedure that use in order to know or to measure something in some situation by using certain rule or method. Learning result test is a group of questions or tasks that have to answered or finished by students in order to measure the progress of students learning.

Brown defined test as "a method of measuring a person's ability or knowledge in a given domain, with an emphasis on the 
concepts of method and measuring. Tests are instruments that are usually carefully designed and that have identifiable scoring rubrics. Tests are prepared administrative procedures that was occupy identifiable time periods in a curriculum when learners muster all their faculties to over peak performances, knowing that their responses are being measured and evaluated". (H. Douglas Brown, 2007: 445). In line with Brown, Subiyanto stated that test is one of measuring tools that used as a consideration in evaluation. (Subiyanto, 1988: 69).

According to Arikunto, test is a tool or a procedure that used to know or to measure something in some situation by using certain rules. (Suharsimi Arikunto, 2005: 3). Also, "tests can be of value in diagnosing an individual's special aptitudes and abilities". (Kenneth D. Hopkins, et al. 1990: 16). Hence, testing is a specific procedure that teachers and examiners employ to try to measure ability in the language using what learners show they know as an indicator of their ability. (Tricia Hedge, 2008: 378).

\section{Standardized Test and Non Standardized Test}

"A standardized assessment is one in which the procedures for administering test items are prescribed and well defined. All other assessments are non standardized." (Carl Coelho, et. al. volume 26, number 4, 2005: 224)

Non standardized test procedures serve a variety of purposes, including determining competencies in domains for which there are no standardized test, describing performance in the context of real world settings and cognitive demands and partner supports. (Carl Coelho, et. al. volume 26, number 4, 2005: 223)

One of non standardized tests is teacher made test. In this thesis, the researcher just only focusing on the teacher made test as a non standardized test.
Based on its quality standard, test is classified to standardized test and teacher made test. Ign.Masidjo, 1995: 57). Based on Longman Dictionary of Applied Linguistics, standardized test defined as a test (a) which has been develop from tryouts and experimentation to ensure that it is reliable and valid, (b) for which norms have been established, (c) which provides uniform procedures for administering (time limits, response format, number of questions) and for scoring the test. (Jack Richards, 1985: 271).

Despite the fact, Encyclopedia Brintanica stated that "Standardized tests with carefully defined procedures for administration and scoring to ensure uniformity can achieve broader goals". http://www.britannica.com). Narrowly, standardized test defined as a test that is arranged by an expert team or certain institution professionally.

Standardized test is well known as a good standard test because it has an obvious validity and reliability. Standardized tests which are constructed accurately by one or more test constructor have been piloted scores of times, so that they have a good quality in validity and reliability.

$$
\text { According to Brown, "a }
$$
standardized test presupposes certain standard objectives, or criteria, that are held constant across one form of the test to another". (H. Douglas Brown, 2004:67).

However, even has a high-quality in validity and reliability, standardized test has limitation. According to Brown $(\mathrm{H}$. Douglas Brown, 2004:68). there are two disadvantages of standardized test. First, disadvantages center largely on the inappropriate use of such test, for example, using an overall proficiency test as an achievement test simply because of the convenience of standardization. Second, another disadvantage is the potential misunderstanding of the difference between direct and indirect and indirect testing. 


\section{i. Advantages of Standardized Test}

Standardized tests tend to focus on general skills and kinds of information that would be included among educational objectives of most school districts. (Kenneth D. Hopkins, et al. 1990: 16).

The norm provided by standardized tests offer the user a comparison with an external group; this comparison is important for such purposes as quality control, curricular evaluation, academic and vocational guidance and counseling, and identification of exceptional students. Kenneth D. Hopkins, et al. 1990: 16).

ii. Mistakes Sometimes Made in Using Standardized Test (Walter R. Borg and Meredith D. Gall, 1989: 313)

1. Researcher select the first test that is found rather than systematically selecting the test most appropriate for the research problem

2. Uses sub scores from a test without checking their validity and reliability

3. Does not check the content of an achievement test to determine whether it corresponds to the content covered in the schools that will be used in the research

4. Selects a test instrument that the researcher is not qualified to administer and interpret

5. Fails to check the content of a personality test to determine whether it is likely to cause public relations difficulties.

\section{Teacher Made-Test}

Central to school's evaluation process are teacher-made tests. Such instruments are designed to appraise the outcomes of local classroom instruction. Generally, commercial standardized tests are too general in scope and too inflexible to meet the special requirements of each subject or group of students, plus other diversified elements involved. Preemon Nakarin, http://sichon.wu.ac.th). iii. The Quality of English Teacher-Made Tests

According to Arikunto (2005), the teacher made test is "test that arranged by the teacher in the same type of question and consist of the same amount of materials or knowledge which are included by teacher made test". (Arikunto, 2005: 146). Further, teacher made test is "tests and other measures that are planned, assembled, written, or otherwise prepared by teachers for use with particular groups of students". (http://www.education.com). It is possible that the test not yet been tested its validity and its reliability.

\section{iv. Functional English Teacher Made-Tests}

Teachers are often as concerned with measuring the language ability of students to think about and use knowledge as they are with measuring the knowledge their students possess. In these instances, tests are needed that permit students some degree of freedom and diversity in their responses to the test questions. There are various types of teacher-made tests which have been formally in use in measuring the teaching-learning outcomes effectively in schools of all levels; namely, essay tests, shortanswer tests, matching tests, true-false tests, and multiple-choice tests. (Preemon Nakarin, http://sichon.wu.ac.th).

\section{The Scope of English SKL Academic Year 2010 and 2011}

The following are the English SKL academic year 2010 and 2011 at first, second and third year, as can be seen in the following table:

Table 2

English SKL academic year 2010 and 2011

\begin{tabular}{c|l|l}
\hline No. & \multicolumn{1}{|c|}{ SKL } & \multicolumn{1}{c}{ Indicator } \\
\hline 1. & Listening & $\begin{array}{l}\text { Determining common } \\
\text { picture/certain } \\
\text { information/ detailed }\end{array}$ \\
\hline
\end{tabular}




\begin{tabular}{|c|c|c|}
\hline & \multirow{5}{*}{$\begin{array}{l}\text { meaning in } \\
\text { interpersonal } \\
\text { and } \\
\text { transactional } \\
\text { oral discourse, } \\
\text { formally and } \\
\text { also informal in } \\
\text { the form of } \\
\text { short functional } \\
\text { text, recount, } \\
\text { narrative, } \\
\text { procedure, } \\
\text { descriptive, } \\
\text { item news, } \\
\text { report, } \\
\text { exposition } \\
\text { analytical, } \\
\text { exposition } \\
\text { hortatory, } \\
\text { explanation, } \\
\text { discussion, and } \\
\text { review in } \\
\text { everyday life } \\
\text { context. }\end{array}$} & $\begin{array}{l}\text { letter information of } \\
\text { oral conversation of } \\
\text { interpersonal or } \\
\text { transactional sounded } \\
\text { off. }\end{array}$ \\
\hline & & $\begin{array}{l}\text { Responding / equipping } \\
\text { unconvinced } \\
\text { expression, satisfy and } \\
\text { dissatisfy, expressing } \\
\text { how to ask opinion, } \\
\text { promising, expectation } \\
\text { expression of } \\
\text { interpersonal or } \\
\text { transactional oral } \\
\text { conversation that } \\
\text { sounded off. }\end{array}$ \\
\hline & & $\begin{array}{l}\text { Determining a matching } \\
\text { picture with } \\
\text { conversation of } \\
\text { interpersonal or } \\
\text { transactional of oral } \\
\text { conversation that } \\
\text { sounded off. }\end{array}$ \\
\hline & & $\begin{array}{l}\text { Determining a matching } \\
\text { picture with the text of } \\
\text { a monologue text that } \\
\text { sounded off. }\end{array}$ \\
\hline & & $\begin{array}{l}\text { Determining common } \\
\text { picture/certain } \\
\text { information/detailed } \\
\text { letter information of } \\
\text { monologue text that } \\
\text { sounded off. }\end{array}$ \\
\hline 2. & $\begin{array}{l}\text { Reading } \\
\text { Comprehending } \\
\text { meaning in } \\
\text { discourse } \\
\text { written } \\
\text { formally and }\end{array}$ & $\begin{array}{l}\text { Determining common } \\
\text { picture/word } \\
\text { reference/word } \\
\text { meaning in a text from } \\
\text { a short functional text } \\
\text { in the form of presented } \\
\text { message. }\end{array}$ \\
\hline & $\begin{array}{l}\text { the form of } \\
\text { short functional } \\
\text { text, recount, } \\
\text { narrative, }\end{array}$ & $\begin{array}{l}\text { Determining common } \\
\text { picture/certain } \\
\text { information/detailed } \\
\text { letter information in a } \\
\text { text of short functional }\end{array}$ \\
\hline
\end{tabular}

procedure,
descriptive,
item news,
report,
exposition
analytical,
exposition
hortatory,
explanation,
discussion, and
review in
everyday life
context.

text in the form of presented announcement.

Determining common picture/certain information/word meaning in a text of short functional text in form of advertisement/presented brochure.

\section{Determining common picture/certain information, detailed letter information/ word meaning/phrase from a text in form of presented news item.}

Determining certain information/main idea of paragraph/implicit information/word meaning/phrase from within text in form of presented recount.

Determining common picture/certain information/detailed letter information/ communicative target/word meaning/ phrase from a text in form of presented explanation.

Determining common picture/certain information/main idea of paragraph/ explicit detailed word information/ implicit/word meaning/phrase from within text in form of presented hortatory analytical/exposition. 


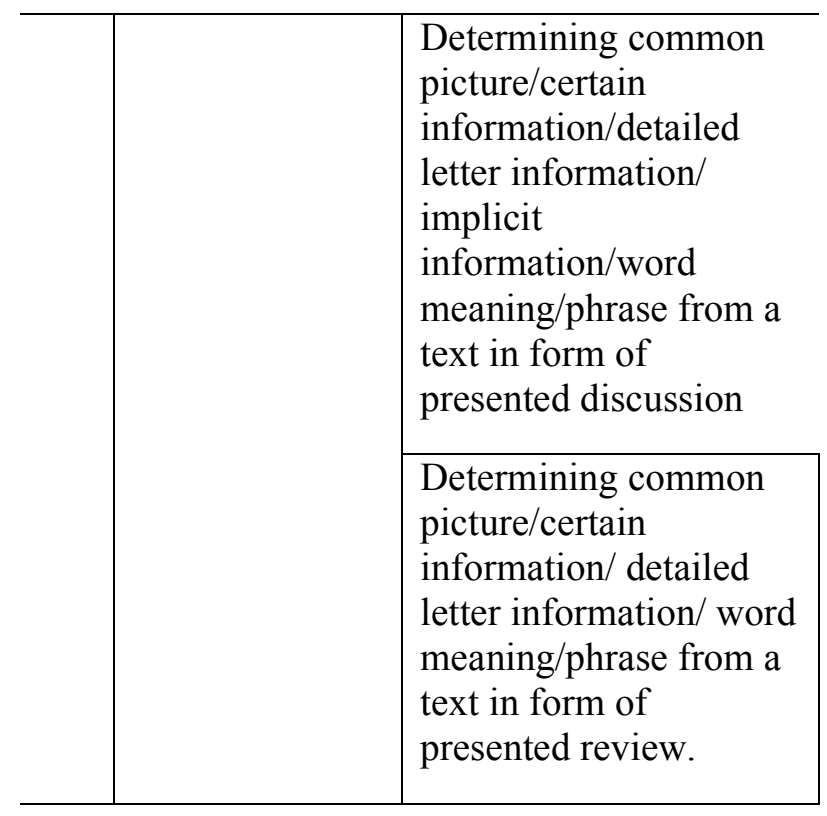

\section{Characteristics National Examination Academic Year 2010 and 2011}

According to Permendiknas no. 45 academic year 2010 about characteristics of students passing at junior high school, senior high school academic year 2010 and 2011 and Permendiknas no. 45 academic year 2010 about the implementation of National Final Examination, there are some differences in running between the National examination academic year 2010 and 2011 and the national examination last year. The critical alterations for the management of this year are: (http://smppegandon.net/2011/01/07/kriteria)

a. There is no repetition for the test

b. General examination completed before the National Examination

c. Value of skill competent:

1. Vocational theory test, problem master of center, scoring by school.

2. Value of skill competent represent one of the national test value.

3. Value of skill competent is alliance of practice $70 \%$ and theory $30 \%$. d. Pass characteristic of National Examination:

1. Pass criterion of National Examination involves school value

2. Merger of National Examination rate and school value is executed by center

3. School assessment for senior high school is coalition of assessment notification at semester 3, 4, and 5; and for junior high school, school assessment is coalition of assessment notification at semester 1, 2, 3, 4, and 5.

4. Pass criterion of National Examination: there is no alliance value below/under 4 and mean is $\geq$ 5.50; especially for Sekolah Menengah Kejuruan (SMK), the skill competent value has to $\geq 7.00$.

\section{CONCLUSION}

On the basis of the research finding, the study comes to the following conclusions:

First of all, one of the most important things that have to be conducted by the teacher in order to know the results of teaching learning process is evaluation. Sometimes the teacher's evaluation, especially tryout, did not reflect what the students should achieve in order to prepare the students in following the national examination. Consequently, there are a lot of students cannot pass the final national examination.

Second, evaluation is a process of assessing and measuring the students' achievement by using some tools in teaching learning process. Interview and document analysis are some technique used by the researcher in order to find out the data that the researcher needed to answer the research question of her thesis. More than fifty percent of tryout out test items is not relevant to the national test items. Also, the final national test items were designed with higher cognitive 
domain than teacher made test items. It means the teacher made test items (tryout) is more superficial than final national test items. That is why the students who can pass the tryout test which is made in teacher cannot pass the national final examination test (standardized test).

\section{REFERENCES}

. (2007). Teaching by Principles; an Interactive Approach to Language Pedagogy, USA: Longman.

Arikunto, S. (2005). Dasar-Dasar Evaluasi Pendidikan, Jakarta: Bumi Aksara.

Borg, W. R. \& Gall. M. D. (1989). Educational Research; an Introduction, Fifth Edition, New York: Longman.

Brown, H. D. (2004). Language Assessment Principles and Classroom Practices, USA: Longman.

Burns, M. K. (2008). What is Formative Evaluation? Minnesota Center for Reading Research.

Cartono. (2007). Assesmen dalam Pembelajaran Sains, Jakarta: Program Doktor Pendidikan IPA Sekolah Pasca Sarjana Universitas Indonesia.

Cebula, B. A. J. P. (1926). Tests, Measurement, and Evaluation; a Developmental Approach, USA: Addison-Wesley Publishing Company.

Coelho, C. et. al. (2005). Seminars in Speech and Language, volume 26, number 4.

Hale, J. (2011). The 3 Basic Types of Descriptive Research Methods. Psych Central. Retrieved on June 17, 2012. in http://psychcentral.com/blog/archives/2 011/09/27/the-3-basic-types-ofdescriptive-research-methods/.
Hamzah, B.U. (2006). Perencanaan Pembelajaran. Jakarta: Bumi Aksara.

Hardiato, D. Perencanaan Pembelajaran dalam Kerangka Penyelenggaraan Pelatihan. Retrieved on February 28, 2012. in http://staff.uny.ac.id/.pdf/.

Hedge, T. (2008). Teaching and Learning in the Language Classroom, New York: Oxford University Press.

Hopkins, K.D.J.C.B.R. (1990). Educational and Psychological Measurement and Evaluation, seventh edition, New Jersey: Prentice Hall.

Hornby, A.S. (2000). Oxford Advanced Learner's Dictionary of Current English, Sixth Edition, New York: Oxford University Press.

http://smppegandon.net/2011/01/07/kriteria Kelulusan dan pelaksanaan UN Tahun 2010/2011, retrieved on June 13, 2012.

http://www.anneahira.com/pengertian-ujiannasional.htm, retrieved on March 26, 2012.

http://www.britannica.com/ebchecked/topic/48 1664/. Retrieved on June 16, 2011 psychological-testing/23858/Teachermade-versus-standardized-tests.

http://www.education.com/definition/teachermade-tests/, Retrieved on June 16, 2011.

http://www.funduszestrukturalne.gov.pl/NR/rdo nlyres/C81E88FA-0F99-4233-8B3A0C9FFF2C0695/14716/Ewaluacjakwest ieog $\% \mathrm{C} 3 \% \mathrm{~B} 3 \ln e e n 1 . d o c$, Retrieved on June, $13^{\text {rd }} 2012$.

http://www.ihmctan.edu/PDF/notes/Research Methodology.pdf, Retrieved at June, $17^{\text {th }} 2012$.

http://www.interview.htm. Retrieved on March 26, 2012. 
http://www.scribd.com/pakferdy996/d/4492632 8-SKL-UN-SMA-2011. Retrieved on April 2, 2012.

http://www.thefreedictionary.com/relevancy. Retrieved on March 26, 2012.

Margono. (2005). Metode Penelitian Pendidikan, Jakarta: PT. Rineka Cipta.

Masidjo, (1995). Ign. Penilaian Pencapaian Hasil Belajar Siswa di Sekolah, Yogyakarta: Kanisius.

Moloeng, L.J. (2008). Metodologi Penelitian Kualitatif, Edisi Revisi, Bandung: PT. Remaja Rosdakarya.

Nakarin, P. Building Effective English TeacherMade Tests: a Major KPI for Thai ESP Teachers. Retrieved on June 13, 2012.http://sichon.wu.ac.th/file/arts20090212-102632-Zqta5.pdf,.

Nasution, S. (1995). Kurikulum dan Pengajaran, Jakarta: Bumi Aksara.

Nawawi, H.H. (1991). Metodologi Penelitian Sosial, Yogyakarta: Gajah Mada University Press.

Piper, D. \& Scharf, A. (2004). Descriptive Analysis-state of the Art and Recent Developments. Retrieved on June 17, 2012.

Posner, G.J. (2004). Analyzing and curriculum, USA: McGraw-Hill Companies.

Purwanto, N. (2004). Prinsip-Prinsip dan Tehnik Evaluasi Pengajaran. Bandung: Remaja Rosda Karya.

Purwanto. Pengertian Evaluasi, Pengukuran dan Penilaian dalam Dunia Pendidikan. Navel's Blog.htm, Retrieved on June 16, 2011.

Richards, J.J.P.H.W. (1985). Longman Dictionary of Applied Linguistics, England: Longman.
Strider, C. Qualitative Descriptive Research Method, (Online) http://www.eHow.pdf, Retrieved on June 13, 2012.

Subagyo, P.J. (1987). Metode Penelitian Dalam suatu Pengantar Kepada Teori Tes dan Pengukuran, Jakarta: Departemen Pendidikan dan Kebudayaan Direktorat Jenderal Pendidikan Tinggi Proyek Pengembangan Lembaga Pendidikan Tenaga Kependidikan.

Subagyo, P.J. (1991). Metode Penelitian dalam Teori dan Praktek, Jakarta: Rineka Cipta.

Subiyanto, J. (1998). Evaluasi Pendidikan Ilmu Pengetahuan Alam, Jakarta: Departemen Pendidikan dan Kebudayaan Direktorat Jenderal Pendidikan Tinggi Proyek Pengembangan Lembaga Pendidikan Tenaga Kependidikan.

Sudjono. (2005). Anas. Pengantar Evaluasi Pendidikan, Jakarta: PT Raja Grafindo Persada Utama.

Taras, M. Assessment-Summative and Formative-some Theoretical Reflection, British Journal of Educational Studies, vol. 53, No. 4, 2005.

Tayibnapis, F. Y. (2000). Evaluasi Program, Jakarta: PT. Rineka Cipta. 